NBER WORKING PAPER SERIES

\title{
HAVE FALLING TARIFFS AND TRANSPORTATION COSTS RAISED U.S. WAGE INEQUALITY?
}

\author{
Jonathan E. Haskel \\ Matthew J. Slaughter \\ Working Paper 7539 \\ http://www.nber.org/papers/w7539 \\ NATIONAL BUREAU OF ECONOMIC RESEARCH \\ 1050 Massachusetts Avenue \\ Cambridge, MA 02138 \\ February 2000
}

For financial support we thank the U.K. Economic and Social Research Council for grants R000236653 and R000222730 and we thank the Russell Sage Foundation. For research assistance we thank Ylva Heden; for data help we thank Andrew Bernard and Robert Feenstra. The views expressed herein are those of the authors and not necessarily those of the National Bureau of Economic Research.

(C) 2000 by Jonathan E. Haskel and Matthew J. Slaughter. All rights reserved. Short sections of text, not to exceed two paragraphs, may be quoted without explicit permission provided that full credit, including $\odot$ notice, is given to the source. 
Have Falling Tariffs and Transportation Costs Raised U.S. Wage Inequality?

Jonathan E. Haskel and Matthew J. Slaughter

NBER Working Paper No. 7539

February 2000

JEL No. F16, J31

\begin{abstract}
$\underline{\text { ABSTRACT }}$
A number of studies have tried to gauge the effect of international trade on the rising U.S. skill premium by examining whether product prices in unskill-intensive sectors have fallen relative to prices in skill-intensive sectors. However, these studies do not estimate what share of domestic product-price changes is due to trade barriers. This paper attempts to address this issue by analyzing not the sector bias of price changes but rather the sector bias of price changes induced by changes in U.S. tariffs and transportation costs. We find that in both the 1970s and 1980s, level cuts in tariffs and transportation costs levels were concentrated in the unskill-intensive sectors. If pass-through of trade barriers to product prices is uniform across all sectors, then this suggests falls in tariffs and transportation costs were mandating a rise in the U.S. skill premium. But despite this suggestive evidence, we estimate that the price changes induced by tariffs or transportation costs mandated a rise in the skill premium that was mostly statistically insignificant. Thus, we do not find strong evidence that falling tariffs and transport costs, working through price changes, mandated rises in inequality.
\end{abstract}

Jonathan E. Haskel

Department of Economics Queen Mary and Westfield College

University of London London E1 4NS ENGLAND

and CEPR

j.e.haskel@qmw.ac.uk
Matthew J. Slaughter

Department of Economics

Dartmouth College

309 Rockefeller Hall

Hanover, NH 03755

and NBER

slaughter@dartmouth.edu 


\section{Introduction}

A number of studies have tried to estimate the effect of international trade on the U.S. skill premium by examining whether product prices in unskill-intensive sectors have fallen relative to prices in skillintensive sectors (see Slaughter, 1999 for a survey). These studies are based on the intuition of the Stolper-Samuelson theorem, which links changes in a country's domestic product prices to changes in its factor prices (see Deardorff, 1994 for a survey). The thrust of the theorem is that the skill premium tends to rise if price increases are concentrated in skill-intensive industries, i.e., if price increases are "sector biased" towards skill-intensive sectors.

A potential limitation of these "product price" (or "mandated wage") studies is they do not estimate what share of domestic-price changes is due to some exogenous aspect of international trade. Of course, if the United States were a small open economy then any change in U.S. tradable prices would be caused by changes in world trading conditions. Many price studies have implicitly or explicitly assumed this. It is likely, however, that U.S. tradable prices depend both on trade-related forces and on domestic forces (e.g., oligopolistic interaction). Hence the sector bias of price changes may convey no information about the sector bias, and so wage effects, of trade-related forces. ${ }^{1}$

This paper attempts to address this limitation by analyzing not the sector bias of price changes but rather the sector bias of price changes induced by changes in U.S. tariffs and transportation costs. This allows us to ask a more precisely focused question, "have changes in U.S. tariffs and transportation costs changed the U.S. skill premium?" This is a narrower question than that of many existing productprice studies, but by focusing on two plausibly exogenous aspects of international trade it is arguably better-defined. ${ }^{2}$

The details of the study are set out below, but briefly, our empirical work is based on the production side of Heckscher-Ohlin theory for a single country. ${ }^{3}$ This model has motivated most existing product-

\footnotetext{
${ }^{1}$ Freeman (1995, p. 29), for example, writes: "Perhaps the biggest problem with these [product-price] studies is that they ignore potential determinants of changes in sectoral prices.... Finding relative price declines in sectors that intensively use less-skilled labor may be necessary to establish a trade effect that operates through prices, but it is not sufficient to establish a trade effect in a world where many forces influence relative prices."

2 As Deardorff and Hakura (1994, p. 81) have commented, "How does a reduction in trade barriers affect wages? This interpretation [of the question 'How does trade affect wages?'] is motivated most directly by the theorems of trade theory. Since barriers may be plausibly taken as exogenous, barring political economy considerations, it is a sensible question."

${ }^{3}$ The model assumes that an economy contains many industries of differing skill intensity and that intersectoral factor mobility ensures zero abnormal profits. It is important to stress that we consider only the production side of only a single country. Thus
} 
price studies, for it provides a method for measuring the factor-price effects of the sector bias of product-price changes. However, no mandated-wage study has related these product prices to tariffs and transportation costs. Following Feenstra and Hanson (1999) and Haskel and Slaughter (1999), we first estimate the relationship between changes in U.S. domestic product prices and changes in tariffs, transportation costs, and other underlying forces. This allows us to calculate the portion of productprice changes due to changes in our trade barriers. We then estimate wage changes due to the sector bias of these trade-barrier-induced product-price changes. ${ }^{4}$

Our empirical analysis uses four-digit SIC data covering all of U.S. manufacturing from 1974 through 1988. We find that in both the 1970s and 1980s level cuts in tariffs and transportation costs were concentrated in the unskill-intensive sectors. If pass-through of trade barriers to product prices is uniform across all sectors, then this suggests changes in tariffs and transportation costs were mandating a rise in the U.S. skill premium. But despite this suggestive evidence, the price changes induced by tariffs or transportation costs mandated a rise in the skill premium that was mostly statistically insignificant. Thus, we do not find strong evidence that falling tariffs and transport costs, working through price changes, mandated rises in inequality.

The remainder of this paper proceeds as follows. In the next section we set out the mandated-wage methodology. Section 3 describes our data, and section 4 sets out our results. Section 5 concludes, with a discussion relating our results to existing product-price studies.

\section{Sector Bias and the Mandated-Wage Methodology}

The production side of the HO model assumes an economy with sectors of different factor intensity (at the same relative factor prices) and factors with complete mobility across sectors. Aggregate demand for skilled workers relative to unskilled workers (henceforth, aggregate relative labour demand) changes whenever factors flow across sectors. For example, if factors flow to a skill-intensive sector

our framework does not imply many results of HO trade theory such as factor price equalization (FPE) (Samuelson, 1948), i.e., that each factor receives the same wage world-wide. These results require additional cross-country assumptions such as identical production technologies and sufficiently similar tastes. Our analysis neither imposes any assumptions on cross-country technology similarity nor any assumptions on the consumption side.

${ }^{4}$ See Haskel and Slaughter (1999) for a similar analysis of tariff changes for the United Kingdom. Feenstra and Hanson (1999), using U.S. data, regress the sum of price and TFP changes on computerization and outsourcing and then use the predicted values to generate the effects of these two variables on relative wages working through technology and prices together. Also, Hanson and Harrison (1999) regress price changes on tariff changes and import-license changes for Mexico, but they do not use these estimates to estimate wage effects as in the mandated-wage studies. 
then aggregate relative labour demand rises. These factor flows are endogenously caused by changes in intersectoral profitability, which in turn are caused by changes in product prices or technology. Hence factor prices adjust to any shocks to aggregate relative labour demand to restore, if the economy is competitive, zero profits in all sectors.

This process can be formalized by supposing the economy produces $I$ different tradable goods, each of which requires some combination of $J$ primary factors and $I$ intermediate inputs. Assuming zero profits in each sector $i$, we write

$$
p_{i}{ }^{\mathrm{G}}=\sum_{j \in J} a_{j i} w_{j}+\sum_{i \in I} b_{i i} p_{i}^{G} \quad i=1 \ldots I
$$

where $p_{i}{ }^{G}$ is the domestic gross-output price in sector $i ; w_{j}$ is the unit cost of the $j$ th input; $a_{j i}$ is the (endogenously determined) employment of input $j$ per unit of output in sector $i$; and $b_{i i}$ is the amount of intermediate input $i$ required to produce a unit of good $i$. There are $I$ equations in (1), one for each sector where production occurs. Note that with intersectoral factor mobility, wages $w_{j}$ in (1) are not indexed by sector $i$. In the special case of a small open economy, $p_{i}{ }^{G}$ is also the world price. Totally differentiating (1) with respect to time gives

$$
\Delta \log p_{i t}+\Delta \log T F P_{i t}=\sum_{j \in J} V_{j i t} \Delta \log w_{j t}
$$

where $\Delta \log p_{i t}=\left[\Delta \log p_{i t}{ }^{G}-\Sigma V_{\mathrm{iit}} \Delta \log p_{i t}{ }^{G}\right]$ is the change in value added prices, $V_{j i t}$ is the share of factor $j$ in total costs in sector $i$ at time $t$; and $\Delta \log T F P_{i t}$ is the growth in total factor productivity for sector $i$. The final term in (2), $\Delta \log w_{j t}$, is the wage change for factor $j$, which again is economy-wide since all factors are mobile across sectors.

Equation (2) shows how economy-wide factor prices $\left(\Delta \log w_{j t}\right)$ adjust to changes in product prices $\left(\Delta \log p_{i t}\right)$ or technology $\left(\Delta \log T F P_{i t}\right)$ to restore zero profits in all sectors. In (2), the wage effect of price changes depends on their sector bias. Price increases in a sector tend to raise (reduce) the relative wages of factors employed relatively intensively (unintensively) in that sector, where intensity is defined 
by $V_{i j t}$. This sector-bias intuition linking product prices and wages is the essence of many versions of the Stolper-Samuelson theorem (Deardorff, 1994). ${ }^{5}$

Equation (2) is the foundation for the product-price studies described in the introduction (see Baldwin and Cain, 1997 and Leamer, 1998 for a more detailed motivation). A regression of $\Delta \log p_{i t}$ on the factor shares $V_{i j t}$ yields estimates of economy-wide factor-price changes consistent with zero profits in the face of changes in product prices. Almost all product-price studies have treated product prices as exogenous. Following Feenstra and Hanson (1999) and Haskel and Slaughter (1999), we treat them as endogenous. To implement this, we proceed in two stages. First we regress price changes on a set of causal factors, $Z_{p r i}$, which are assumed to drive price changes over some period:

$$
\Delta \log p_{\mathrm{it}}=\sum_{\text {pri } \in S_{\mathrm{pri}}} Z_{\mathrm{pri}, \mathrm{it}} \delta_{\mathrm{pri,} \mathrm{t}}+\varepsilon_{\mathrm{it}}
$$

where $\varepsilon_{i t}$ is a random error. We try several different specifications of $Z_{p r i}$. Along with our key forces of U.S. tariffs and transportation costs, we will also include in $Z_{p r i}$ world output, exchange rates, capitallabor ratios, and four-firm concentration ratios.

In the second stage we regress the contribution to $\Delta \log p_{i t}$ of each underlying variable, $\hat{\delta} Z_{p r i}$, on cost shares

$$
\hat{\boldsymbol{\delta}}_{p r i} \mathrm{Z}_{p r i, i t}=\sum_{j \in J} V_{j i t} \boldsymbol{\gamma}_{j t, p r i}+\boldsymbol{\varepsilon}_{i t}^{\prime}
$$

The coefficients $\gamma_{j t, \text { pri }}$ give the wage changes mandated by the sector bias of each structural force working through $\Delta \log p_{i t}$. For example, including tariff changes in (3) determines the amount of productprice variation accounted for by tariff changes. Having that amount be the regressand in (4) then determines the wage changes mandated by the sector bias of tariff changes working through product prices.

Before proceeding to the estimates, there are four points worth noting. First, how do the structural forces $Z_{p r i}$ fit into our overall model? The logic of sector bias derives from three key assumptions: zero abnormal profits, differing skill intensities across sectors, and factor mobility across sectors. Thus, the question becomes whether our structural forces are inconsistent with these assumptions.

\footnotetext{
${ }^{5}$ For the sector-bias intuition linking technology changes to wages, see Findlay and Grubert (1959).
} 
Our trade-related variables, tariffs and transportation costs, are perfectly consistent with these assumptions. The baseline $\mathrm{HO}$ model is often presented with trade barriers driving a wedge between domestic and world prices. Thus tariffs and transportation costs are consistent with our model. The world-output variable aims to capture some of the determinants of world prices.

Our industry-concentration variables, capital-labor ratios and four-firm concentration ratios, try to capture elements of imperfect competition. Whether this is consistent with the underlying model depends on how imperfect competition operates. Helpman and Krugman (1985) extend the HO model where one sector is monopolistically competitive with entry. This sector still earns zero profits, and price changes still have Stolper-Samuelson wage adjustments (pp. 190-194). Hence imperfect competition can still be consistent with zero profits.

What about imperfect competition with positive profits? If factor prices incorporate rents, this violates the assumption that each factor earns the same price in all sectors. Hence estimates of economy-wide factor-price changes from (4) might be uninformative about actual industry factor-price changes if the latter are driven by changes in industry-specific rents. Concerning wages, a large literature has documented interindustry wage differentials for workers with the same measurable skills and has argued that rent sharing explains these differentials (e.g., Katz and Summers, 1989). But since we analyze changes in economy-wide wages, what matters is whether changes in industry wages are driven mainly by economy-wide changes common to all sectors or by changes in industry differentials. To check this, we computed industry wage differentials as the deviation of industry wages from the economy-wide average and then decomposed decade changes in industry wages into changes in average wages and changes in differentials. Changes in differentials account for only about $15 \%$ of industry wage changes. Thus, differentials clearly exist in levels, but changes in industry wages are driven largely by changes in economy-wide wages, not in differentials. This is consistent with evidence (e.g., Katz and Summers, 1989) that interindustry wage differentials are stable over time.

A second issue is the nature of the link between trade barriers and product prices in (3) and (4). In (3), the estimated coefficients $\boldsymbol{\delta}_{p r i}$ do not vary by industry: this assumes the same pass-through rate from trade barriers to product prices across all industries. However, Feenstra (1989) models how pass-through rates depend on industry structure, and finds the pass-through of tariff changes to U.S. 
consumer prices varies across product groups. To allow pass-through rates to depend on market structure we interact our trade barriers with market-structure variables.

More generally, this issue of common pass-through highlights that our estimates of wage changes mandated by trade-barrier-induced price changes depend crucially on our estimates of $\delta_{p r i}$. For each trade barrier, our regressand in (4) is that barrier itself multiplied by its $\delta_{p r i}$ coefficient. A poor estimate of $\boldsymbol{\delta}_{p r i}$ means a poor estimate of wage changes mandated by trade barriers. For example, assuming no Metlzer paradoxes, we expect pass-through to be positive (independent of whether it is common across industries): increases in trade barriers should lead to increases in domestic product prices. But if (3) is badly specified, e.g., due to omitted-variables bias, estimated $\delta_{p r i}$ might be negative.

It therefore seems informative to regress our raw trade-barrier changes on factor-cost shares:

$$
\Delta T A R I F F_{i t}=\sum_{j \in J} V_{j i t} \gamma_{j t}^{\prime}+\varepsilon_{1, i t}
$$

and

$$
\Delta T R A N S_{i t}=\sum_{j \in J} V_{j i t} \gamma_{j t}^{\prime \prime}+\varepsilon_{2, i t}
$$

We interpret the coefficient estimates in (5) and (6) to describe the sector bias of changes in tariffs and transportation costs, respectively. Assuming that these changes tend to be negative (i.e., that trade barriers are generally falling), larger (smaller) coefficients on the skilled-labor cost share than on the unskilled-labor cost share indicate trade-barrier cuts are concentrated in the unskill-intensive (skillintensive) sectors. For each trade barrier this provides qualitative information about the direction of wage changes mandated by these cuts, meditated through product-price changes, if there is a single, positive pass-through rate $\delta_{p r i}$ for that barrier. Thus (5) and (6) provide a qualitative indication of wage pressures mandated by trade-barrier changes under this assumption.

A third issue is the role of factor supplies. In the model, national factor supplies are one of the forces determining $I$, the equilibrium range of products produced. Changes in factor supplies can affect wages if they change the range of producing sectors (and thus change which sectors enter (1) and (2)). Even if the product mix does not change, changes in factor supplies are absorbed through changes in the quantities of output, which in turn can affect wages if product prices change. 
Finally, for simplicity our framework has no nontraded sector. In fact, a nontraded sector can easily be incorporated. With nontraded sectors, so long as the number of tradable goods at least equals the number of primary factors, national wages are still determined by the zero-profit conditions of the tradable sectors only. Importantly, in this case nontraded industries need not be included in the empirical estimation. Nontraded product prices are endogenously determined by nontraded production technology and by national wages. Technical progress in nontradables does not affect wages; instead, it lowers nontraded prices.

\section{Data, Specification, and Econometrics}

The analysis in equations (3) through (6) requires industry-year data on trade barriers, product prices, and factor cost shares. Tariff data come from Magee (1998), transportation-cost data from Feenstra (1996), and most other data from the NBER Productivity Data Base (1997). Our full data set covers four-digit SIC (revision 1972) manufacturing industries 1974 through 1988, the first and last years of our tariff data. We date the 1970s from 1974 through 1979 and the 1980s from 1979 through 1988. Like earlier mandated-wage studies, we choose several-year changes to be consistent with the long-run nature of the HO framework. We choose 1979 as the break point between decades because it marks the turning point in the U.S. skill premium for our data (and for other skill measures as well).

Since trade barriers are central to our study, they bear particular discussion. For each industryyear, tariff rates measure total tariff duties collected as a share of imports valued free on board (f.o.b.). In a few cases, the Magee (1998) tariffs are not reported below the three-digit SIC level; accordingly, these tariffs are set equal across the constituent four-digit industries. We interpret variation in these tariffs as indicators of changes in statutory commercial policy.

There are three potential problems with this interpretation. First, as is well known, our tariff measure is biased downwards since imports subject to high or prohibitive tariffs receive little or no weight. It is not clear how this would affect the variation of interest, namely, the sector bias of tariff-rate variation. Second, changing composition of imported products within four-digit industries can alter our tariff measure without any changes in statutory commercial policy. However, Irwin (1998) reports very high correlations between tariff measures like ours and fixed-weight measures. Finally, if tariffs are 
specific rather than ad valorem then our tariff measure can change with import-price changes without any changes in statutory commercial policy. ${ }^{6}$ Crucini (1994) and Irwin (1998) demonstrate this issue mattered greatly for U.S. tariffs in the century before 1970. But Irwin (1998) reports that specific tariffs accounted for only 34 percent of the lines in U.S. tariff code in 1973 and that the Tokyo Round of the GATT, concluded in 1979, converted many U.S. specific tariffs to ad valorem tariffs. In addition, Lawrence and Slaughter (1993) and Baldwin and Cain (1997) report no clear sector bias to U.S. import-price changes in the 1980s. Overall, despite these potential difficulties we interpret our tariff measure to be informative about statutory commercial policy. ${ }^{7}$

Parallel to the tariff measures, transportation costs are calculated as the difference between imports valued cost, insurance, freight and imports valued f.o.b., all as a share of imports valued f.o.b.. Thus, our transportation costs capture the actual cost of shipping and insuring goods. Like our tariffs, these transportation costs face potential problems of downward bias and aggregation. We do not regard these problems as prohibitive, as these costs are highly correlated with bilateral trade flows (Hummels, 1999).

Most of our other data come from the NBER Productivity Data Base, an industry-year panel based on U.S. Censuses of Production and Annual Surveys of Manufacturing. These data report prices and quantities of output, non-production labor, production labor, capital, and intermediate inputs (for details see Bartelsman and Gray, 1996). $\Delta \log T F P_{i t}$ is calculated using data on both labour types, capital, and intermediate inputs. We calculated $\Delta \log p_{i t}$, changes in value-added prices, as defined earlier. Because we analyze long changes, cost shares in gross output, $V_{j i t}$, are averages between the first and last years of each decade. We assumed that capital payments equal the value of gross output less the total wage bill and input costs; we do not have good enough data to define capital's payments independently. To construct labor cost shares we use manufacturing-wide (i.e., not industry-specific) wages.

Following many other studies using this data set, we classify non-production workers as moreskilled and production workers as less-skilled. Our measure of U.S. wage inequality is the non-

\footnotetext{
${ }^{6}$ When the tariff is specific (\$t per item), then our tariff measure is $(\mathrm{t} \times \mathrm{q}) /(\mathrm{p} \times \mathrm{q})$ where $\mathrm{p}$ is the price of the imported good and $\mathrm{q}$ its quantity. The tariff measure then changes with changes in $t$ or in $p$.

${ }^{7}$ Ideally we would also analyze nontariff barriers, but we do not know of any broad enough source of data. Harrison (1994) and Pritchett (1996) document disturbingly low empirical correlations among various trade-policy measures. For theoretical analysis of appropriate trade-policy measures see Anderson and Neary $(1996,1999)$.
} 
production/ production wage premium in U.S. manufacturing. ${ }^{8}$ In the 1970 s nominal non-production wages rose by $46.4 \%$ and production wages by $48.2 \%$, implying a $1.8 \%$ fall in the skill premium. In the 1980s the respective wage increases were $67.2 \%$ and $60.5 \%$, a $6.7 \%$ increase in inequality. If tradebarrier cuts helped drive these changes, theory predicts the cuts to be concentrated in skill-intensive sectors in the 1970s and unskill-intensive sectors in the 1980s.

We report results for five specifications of the stage-one equation (3), each of which uses a different set of structural forces based on different assumptions about price-setting in the U.S. economy. These regressions do not explicitly follow from any structural model, so they should be regarded as reducedform specifications. By estimating several specifications we hope to obtain consistent evidence on the key magnitudes of interest.

The first specification follows the textbook $\mathrm{HO}$ model of a small open economy with perfect competition whereby U.S. product prices are world prices plus any wedge introduced by trade barriers such as U.S. tariffs or transportation costs. Making use of the panel nature of the data by pooling both decades, this suggests the following regression

$$
\Delta \log p_{i t}=\delta_{1} \Delta T A R_{i t}+\delta_{2} \Delta T C_{i t}+\mu_{k t}+\lambda_{t}+\varepsilon_{i t}
$$

where $\Delta T A R_{i t}$ is the change in tariffs; $\Delta T C_{i t}$ is the change in transportation costs; $\lambda_{t}$ is a time dummy for the $1970 \mathrm{~s}, \mu_{k t}$ are three-digit industry dummies, allowed to vary in each of the two decade crosssections; and $\varepsilon_{i t}$ is an error term (which we allow to be heteroskedastic). We do not have data on fourdigit changes in world product prices, so the $\mu_{k t}$ proxy for these changes by allowing price variation both across industries and over time (in each decade, world-price changes are assumed constant across all four-digit industries within each three-digit industry).

Our second specification modifies (3a) by adding in some further controls for world supply and demand. This gives

\footnotetext{
${ }^{8}$ This occupational measure is the only skills measure available in these data (a) over a long time period (b) with congruent trade and technology indicators, and (c) at a disaggregated level. On average, non-production workers are more educated than production workers (see Berman et al, 1994), so these occupation data do distinguish skill groups at least to some extent.
} 


$$
\begin{gathered}
\Delta \log p_{i t}=\delta_{1} \Delta T A R_{i t}+\delta_{2} \Delta T C_{i t}+\delta_{3} \Delta E X R A T E_{i t}+\delta_{4} \Delta W O R L D V A_{g t}+\delta_{5} \Delta T F P_{i t} \\
+\mu_{k t}+\lambda_{t}+\varepsilon_{i t}
\end{gathered}
$$

$\triangle \log$ TFP $_{\text {it }}$ proxies world technological change: the United States performs a sizable share of total world R\&D (Keller, 1999), and the recent pattern of U.S. skill-biased technological change has been broadly matched in many other countries (Berman, et al, 1998). EXRATE $E_{i t}$ is a multilateral real exchange rate where country weights are based on bilateral U.S. exports. ${ }^{9}$ WORLDVA $A_{g t}$ is industry world output. $^{10}$

Our third specification still assumes perfect competition but allows the United States to be large, i.e., allows U.S. supply and demand to affect world prices. This suggests that we interact each industry's barriers with a measure of how large the U.S. is in that industry worldwide.

$$
\begin{gathered}
\Delta \log p_{i t}=\delta_{1} \Delta T A R_{i t}+\delta_{11}\left(\Delta T A R_{i t} \times U_{S O U T S H}\right)+\delta_{2} \Delta T C_{i t}+\delta_{21}\left(\Delta T C_{i t} \times U_{S O U T S H}\right) \\
+\delta_{3} \Delta E X R A T E_{i t}+\delta_{4} \Delta \text { WORLDVA }_{g t}+\delta_{5} \Delta T F P_{i t}+\mu_{k t}+\lambda_{t}+\varepsilon_{i t}
\end{gathered}
$$

Here, USOUTSHR Is $_{\text {is }}$ the share of U.S. output in total industry output, which is then interacted with $\Delta T A R_{i t}$ and $\Delta T C_{i t}$. The extent of trade-barrier pass-through to an industry's domestic price may depend on how large the U.S. economy is in that industry worldwide: e.g., larger industries might have less-than-complete pass-through thanks to their ability to lower world prices.

Next, following the evidence in Feenstra (1989) we consider whether trade-barrier pass-through depends on market structure. First, we measure market structure using initial-year capital-labor ratios, denoted $(K / L)_{i t}$, as higher capital intensity may inhibit entry (Bain, 1948)

$$
\begin{array}{r}
\Delta \log p_{i t}=\delta_{1} \Delta T A R_{i t}+\delta_{11}\left(\Delta T A R_{i t} \times(K / L)_{i t}\right)+\delta_{2} \Delta T C_{i t}+\delta_{21}\left(\Delta T C_{i t} \times(K / L)_{i t}\right) \\
+\delta_{3} \Delta E X R A T E_{i t}+\delta_{4} \Delta W O R L D V A_{g t}+\delta_{5} \Delta T F P_{i t}+\mu_{k t}+\lambda_{t}+\varepsilon_{i t}
\end{array}
$$

where $(K / L)_{i t}$ is in levels for each decade's initial year and is interacted with $\Delta T A R_{i t}$ and $\Delta T C_{i t}$. Equation (3d) captures the idea that less-competitive industries with higher values of $(K / L)_{i t}$ may show

\footnotetext{
${ }^{9}$ We thank Andrew Bernard for these data. We obtained virtually identical results using an import-weighted exchange rate. ${ }^{10}$ Note the subscript $g$ indicates this variable is more aggregated than four-digit SIC industries: it varies only by three-digit ISIC industries, roughly 28 total in manufacturing (United Nations, 1996).
} 
less pass-through from barrier cuts to domestic prices. As an alternative measure of concentration we try the industry four-firm concentration ratio, ${ }^{11} C O N C_{i t}$, again interacted with $\triangle T A R_{i t}$ and $\triangle T C_{i t}$, giving

$$
\begin{array}{r}
\Delta \log p_{i t}=\delta_{1} \Delta T A R_{i t}+\delta_{11}\left(\Delta T A R_{i t} \times C O N C_{i t}\right)+\delta_{2} \Delta T C_{i t}+\delta_{21}\left(\Delta T C_{i t} \times C O N C_{i t}\right) \\
+\delta_{3} \Delta E X R A T E_{i t}+\delta_{4} \Delta W O R L D V A_{g t}+\delta_{5} \Delta T F P_{i t}+\mu_{k t}+\lambda_{t}+\varepsilon_{i t}
\end{array}
$$

Equations (3a) through (3e) are all first-stage regressions. Each first-stage regression leads to two second-stage regressions (4), one using the fitted values of tariff changes as the regressand and the other using the fitted values of transportation-cost changes as the regressand. For example, from (7a) we can compute $\hat{\delta}_{1} \triangle T A R_{i t}$. Following (4), we then regress this on the factor shares for skilled labor, unskilled labor and capital: $\hat{\delta}_{1} \Delta T A R_{i t}=\gamma_{s} V_{\text {sit }}+\gamma_{u} V_{\text {uit }}+\gamma_{k} V_{k i t}+\varepsilon_{i t}$. The coefficients $\gamma_{\mathrm{s}}, \gamma_{\mathrm{u}}$ and $\gamma_{\mathrm{k}}$ give the economy-wide changes in skilled, unskilled, and capital prices needed to restore zero profits in the face of the tariff-induced price changes. In specifications (3c) through (3e), the second-stage regressand includes the interacted term, eg., for tariffs in (3c) it is $\hat{\delta}_{1} \Delta T A R+\hat{\boldsymbol{\delta}}_{11}\left(\Delta T A R \times U S O U T S H_{g t}\right)$. We estimate all second-stage regressions separately for each decade.

Before reporting the results, the following points are worth noting. First, it might argued that that prices and trade barriers are jointly determined; in particular, that price declines trigger protectionist calls for tariff increases. This predicts a negative correlation between tariffs and prices which is the opposite of the positive effect of barriers on prices. Hence, endogeneity will bias downwards the tariffs-to-prices causal link.

Second, our first-stage regressions do not contain measures of either U.S. nontariff barriers or world product prices. We know of no broad data on these other trade-related forces (see note 7). To some extent, our three-digit industry dummies control for them. If changes in nontariff barriers are positively correlated with $\triangle T A R_{i t}$ and $\triangle T C_{i t}$, then the estimated effects of $\triangle T A R_{i t}$ and $\triangle T C_{i t}$ overstate the exact contributions of tariffs but pick up the contribution of "total" trade barriers. For world price changes, to the extent they are not picked up by the industry dummies the coefficients on $\triangle T A R_{i t}$ and $\Delta T C_{i t}$ are biased if the deviation of world four-digit prices from their three-digit mean is correlated with $\Delta T A R_{i t}$ and $\Delta T C_{i t}$.

\footnotetext{
11 These concentration ratios come from various Censuses of Manufacturers. To measure starting-year concentrations as closely as possible, for the 1970s we use the average in 1972 and 1977 and for the 1980s the average in 1977 and 1982.
} 
Third, a number of recent papers have considered the theoretical effect of skill-biased technical change on product prices. In the $\mathrm{HO}$ model product prices can be affected by any type of technical change, and since $\triangle T F P_{i t}$ measures both factor-biased and neutral technical change (Berndt and Wood, 1982) we enter this in (3) rather only skill-biased technical change.

Fourth, in (3) through (6) we weight observations by industry employment averaged over the decade; output-weighted or unweighted results were very similar. In (3) we tested all coefficients to see if they varied over the two cross-sections, but none did so significantly. Finally, in (4) the regressands are generated using estimated coefficients from (3); we correct our standard errors following Feenstra and Hanson (1999). ${ }^{12}$ See the Data Appendix for more data description.

\section{Results}

\section{4a. Changes in Trade Barriers and Their Sector Bias}

Table 1 sets out employment-weighted summary statistics for the levels of trade barriers in 1974, 1979 and 1988. In 1974 tariff rates averaged $7.82 \%$ and transport costs $6.72 \%$; by 1988 these averages were down to $4.07 \%$ and $4.97 \%$. Over both decades average barriers fell steadily, as did their standard deviation in all cases but one. Since there are a number of sectors with large rates, the medians are below the means. ${ }^{13}$

Table 2 presents employment-weighted changes in tariffs and transportation costs. The top four rows show level changes. Consistent with Table 1, barrier levels were falling in both decades—more so in the 1980s. The middle four rows show percentage changes. ${ }^{14}$ These look dramatically different from the level changes. Row 5 for the 1970s shows a mean percentage increase in tariff rates of $262.01 \%$ yet a median percentage fall of $7.1 \%$. The difference is accounted for by petroleum refining, which had

\footnotetext{
12 We wish to obtain the "true" standard errors in a regression of the actual part of $\Delta \ln p_{i t}$ accounted for by each structural force ( $\triangle T A R$ for example) on the $V \mathrm{~s}$. The first stage regression returns the estimated part of $\Delta \ln p_{i t}$ accounted for by each structural force, $\hat{\delta}_{1} \Delta T A R_{i t}$ for tariffs for example. Hence the variance/covariance matrix of the errors from the second stage regression of $\hat{\delta}_{1} \Delta T A R_{i t}$ on the $V \mathrm{~s}$ are a combination of errors from the true regression and those from the first stage regression. Feenstra and Hanson (1999) therefore propose recovering the true error variance from the estimated variance/co-variance matrix of errors from the regression of $\hat{\delta}_{1} \triangle T A R_{i t}$ on the $V \mathrm{~s}$ less (a transformation of) the estimated variance/co-variance matrix of errors from the firststage regression use to calculate $\hat{\delta}_{1} \triangle T A R_{i t}$. This problem is that this subtraction can render the true variance as negative and hence we may be unable to calculate the "true" standard errors.

${ }^{13}$ Note there are a small number of industries which had no trade-barrier data in Magee (1998) and Feenstra (1996). We omit these industries from our subsequent analysis.

${ }^{14}$ Percentage changes were calculated as level changes divided by the initial level. In some years transport costs and tariffs are zero. If initial-year rates were zero we set the change to be +200 . If rates were zero in both years we set the change to be 0 .
} 
a percentage tariff increase of 36,962.62\%, thanks to an increase in its tariff rate from 0.0004 in 1974 to 0.1439 in 1979 . This case of a massive percentage increase generated by a modest level increase from a near-zero base-year level explains the other extreme values in Rows 5 through 8 . To dampen these extreme rises, in Rows 9 through 12 we report "arc" proportional changes, defined as the difference in the levels divided by the average of the levels. These proportional changes bound the "birth" of a barrier at $+200 \%$ and the "death" at $200 \%$. $^{15}$ Consistent with the level changes at the top of Table 2, the mean and median arc changes are uniformly negative and also are larger in the 1980s.

Table 2 raises the question of whether level or proportional changes in trade barriers are economically meaningful. An argument in favor of level changes is the following. Suppose initial tariff rates were $100 \%$ in he unskill-intensive sectors but only $0.1 \%$ in the skill-intensive sectors. Now suppose tariffs were eliminated. Would these tariff cuts have any sector bias? In level terms, yes: the deeper tariff cuts would be in the unskill-intensive sectors. But in proportionate terms, no: all sectors would experience a $100 \%$ tariff decline. It seems reasonable to suppose this trade liberalization would tend to lower the price of unskill-intensive products relative to skill-intensive products (and thus mandate a rise in wage inequality). In light of this reasoning our analysis will focus on level changes in trade barriers; for completeness, we will also report the key findings from percentage changes as well. We note that the related study of Hanson and Harrison (1999) also analyzes level changes in trade barriers.

We are not aware that the sector bias of either initial levels of or changes in U.S. tariffs and transportation costs has been documented. For our initial year, 1974, Figure 1 plots the level of industry trade barriers on industry skill intensity measured as the skilled/unskilled unemployment ratio. The clear message of Figure 1 is that U.S. tariffs and transportation costs were initially highest in the unskill-intensive sectors, particularly sectors in textiles (SIC 22), apparel (23), and footwear (31) for tariffs. ${ }^{16}$ Along with Table 2 that showed barriers were, on average, falling in the 1970s and 1980s, Figure 1 suggests the largest level cuts were in the unskill-intensive sectors.

\footnotetext{
15 The arc proportional change is $\left\{\left(\right.\right.$ rate $_{t+1}-$ rate $\left._{t}\right) /\left[(0.5)\left(\right.\right.$ rate $_{t+1}+$ rate $\left.\left.\left._{t}\right)\right]\right\} * 100$. A death (rate $\left.t+1=0\right)$ is $-200 \%$ and a birth $($ rate $=0)$ is $200 \%$. If both rates were zero we set the arc change to be 0 . These arc changes are similar to measures of job creation and destruction used in Davis, et al (1998).

16 To examine the sector bias of barrier levels more formally we also regressed the levels of tariffs and transport costs on the cost shares for 1974, 1979 and 1988. In every case tariffs and transport costs were significantly concentrated in unskilled-intensive
} 
Figure 2 and Table 3 show this to be the case. Figure 2 plots 1970s and 1980s level barrier changes against initial-year skilled/unskilled employment ratios, along with lines of best fit for an employment-weighted regression of level changes on employment ratios. In both decades falls in both tariffs and transport costs were concentrated in the unskill-intensive sectors, with the linear relation significantly positive at $10 \%$ or better. ${ }^{17}$ Table 3 reports results for equations (5) and (6), which regress level barrier changes on factor cost shares. In all four specifications we find the coefficient on $V_{s}$ is significantly larger than that on $V_{u}$ : level cuts in barriers were concentrated in the unskill-intensive sectors. ${ }^{18}$

In sum, these findings suggest that recent declines in U.S. trade barriers were concentrated in the unskill-intensive sectors. This sector bias would tend to mandate a rise in the U.S. skill premium, meditated through product-price changes, if there were a single, positive pass-through rate from these barriers to prices. This would have worked against the actual decline in the U.S. skill premium during the 1970 s but with the actual rise in the 1980s. To examine the mandated wage changes more systematically, we now present our results for equations (3) and (4).

\section{4b. Two-Stage Analysis of Changes in Trade Barriers and the Skill Premium}

Table 4 sets out our estimates of (3a)-(3e). We estimate these by forming a panel of observations for the two cross-sections, 1974-79 and 1979-88. Each equation includes a time dummy and threedigit industry dummies, with observations weighted by average industry employment. The error term is estimated robustly to account for repeated industry observations.

Column 1 shows estimates of (3a), the specification with just $\Delta T A R_{i t}$ and $\Delta T C_{i t}$. Both are correctly signed with $\triangle T A R_{i t}$ significant at the $14 \%$ level. In column 2 we estimate (3b), adding $\triangle E X R A T E_{i t}$, $\triangle W O R L D V A_{g t}$ and $\triangle \ln T F P_{i t}$. This leaves the coefficients on $\triangle T A R_{i t}$ and $\Delta T C_{i t}$ unaffected but the precision of $\Delta T C_{i t}$ is raised (now significant at the $18 \%$ level). Column 3 estimates (3c), interacting

sectors (1974 tariff coefficient on skilled cost share $-29.32(\mathrm{t}=4.30)$, unskilled cost share $57.56(9.18)$, transport cost -29.48 (5.04) and 5.98 (1.48); 1979 tariff -23.61 (3.69), 50.25 (9.01), transport costs -22.58 (3.64), 6.46 (1.49); 1988 tariffs -23.36 (4.23), 38.89 (8.16) and transport costs $-16.11(3.55), 1.48(0.38))$.

${ }^{17}$ In Figure 2a the estimated coefficient is 0.650 , robust $\mathrm{t}$-statistic of 2.586; in Figure $2 \mathrm{~b}$ the estimated coefficient is 0.450 , robust t-statistic of 1.676; in Figure 2c the estimated coefficient is 0.886, robust t-statistic of 3.304; and in Figure 2d the estimated coefficient is 0.826 , robust $t$-statistic of 2.276 .

${ }^{18}$ Using percentage changes in (5) and (6) we find weak evidence that percentage cuts in barriers were concentrated in the unskillintensive sectors: in all four cases $V_{s}$ is larger than $V_{u}$, but not significantly so. The evidence on arc changes is broadly similar, although arc cuts in 1980 s tariffs are insignificantly concentrated in the skill-intensive sectors. 
$\triangle T A R_{i t}$ and $\triangle T C_{i t}$ with the share of US industry output in world industry output $\left(\right.$ USOUTSH $\left._{i t}\right)$. Both the interacted terms are insignificant (the P-value for the joint significance of the interacted terms is reported in the table), and collinearity with the $\triangle T A R_{i t}$ and $\triangle T C_{i t}$ terms seems to have rendered them insignificant, too. In column 4 we use the log capital/labor ratio as the interacted variable, but these are again jointly insignificant. Finally, column 5 uses the four-firm concentration ratio and obtains similarly insignificant results.

What do we learn from Table 4? At best, tariffs and transport costs have a borderline significant effect on prices. In no specification do these barriers have a significant effect at standard levels. This parallels Hanson and Harrison (1999), who find no robust correlation between trade barriers and domestic prices in Mexico. But to estimate wage changes mandated by barriers working through prices, we need to estimate the second-stage equation (4).

Tables 5 and 6 report estimates of (4). Table 5 uses tariff changes as the regressand and Table 6 transportation-cost changes, and both tables report ten different estimates: five different regressands based on five different first-stage regressions of equation (3) from Table 4, each estimated separately on the 1970s and 1980s. To read these tables, consider the top left column in Table 5. It says that in the 1970s tariff cuts, working through product prices as estimated by the specification in column (1) of Table 4, mandated a $3.2 \%$ rise in the nominal skilled wage and a $4.0 \%$ fall in the unskilled wage. This implies a mandated rise in the skill premium of 7.2 percentage points, which was insignificantly different from zero $(\mathrm{t}=1.45)$ at standard significance levels. All other columns are read in the same manner.

There are two important messages to Tables 5 and 6. First, the mandated changes in nominal wages are all much smaller than actual changes. As mentioned earlier, nominal unskilled wages rose by $48.2 \%$ and $60.5 \%$ over the 1970 s and 1980 s, and skilled wages by $46.4 \%$ and $67.2 \%$. The mandated wage changes in Tables 5 and 6 are much smaller, particularly for transportation costs. Changes in barriers account for very little of the actual change in wage levels.

Second, in both decades and across all specifications, both tariffs and transportation costs mandated rises in the U.S. skill premium through their effect on product prices—but in all but two cases these mandated rises are insignificantly different from zero at the $10 \%$ significance level. In both decades tariffs mandated an inequality rise of about two to seven percentage points and transportation 
costs a rise of a bit under one percentage point. This contrasts with an actual fall in the skill premium of 1.8 percentage points in the 1970 s followed by a rise of 6.7 percentage points in the 1980 s. Thus the 1970s estimates suggests that falling barriers were working against actual wage changes, and that other forces more than dominated this effect. The 1980s estimates suggests that falling barriers were contributing to rising inequality, but again, these estimates are mostly insignificantly different from zero.

We tested the robustness of the results in Tables 3 through 6 in a number of ways. We used proportionate changes in trade barriers rather than level changes; we dropped "outlier" industries (e.g., computers and office products); we used output weights rather than employment weights; and in (4) we used initial-period cost shares rather than decade averages. ${ }^{19}$ All checks yielded the same qualitative finding: mostly insignificant mandated changes in the U.S. skill premium.

\section{Conclusion}

Most studies measuring Stolper-Samuelson effects of trade on the U.S. skill premium by looking at changes in product prices have not estimated what share of price variation is due to some exogenous aspect of international trade. In this paper we have tried to estimate the Stolper-Samuelson effects of changes in U.S. tariffs and transport costs building on the mandated-wage framework of earlier product-price studies.

First, we documented that during both the 1970s and 1980s declines in these barriers were concentrated in unskill-intensive sectors. This provides qualitative evidence that changes in tariffs and transportation costs were mandating a rise in the U.S. skill premium if pass-through of trade barriers to product prices is uniform across all sectors. Second, we quantified these mandated wage changes by estimating (a) how much barrier cuts have affected prices and (b) how much this induced effect on prices has changed relative wages. Here we find that the rise in the skill premium mandated by price changes induced by tariffs or transportation costs was mostly statistically insignificant. Thus, there is not strong evidence that falling tariffs and transportation costs mandated rises in inequality working through price changes.

\footnotetext{
${ }^{19}$ Wage changes will presumably affect factor shares over each decade, and thus our calculations of average cost shares. What is crucial in our framework, however, is the cross-section variation in industry factor shares. Their cross-section variation is, in fact, extremely stable over decades, so any induced cross-section variation from changes in wages seems extremely small.
} 
Our results broadly match earlier price studies of the 1980s which found no strong evidence that product-price increases were skill-sector biased: Lawrence and Slaughter (1993), Baldwin and Cain (1997), and Leamer (1998). Our approach differs from these studies in that we try to estimate what share of price variation is due to trade barriers. But our conclusion of no strong trade effects matches theirs. In our analysis, even though we document deeper trade-barrier cuts in the unskill-intensive sectors, these cuts may simply not have been large enough to greatly affect prices. Alternatively, as Hanson and Harrison (1999) discuss, four-digit industry prices may be too aggregated to reveal price pressures from trade-barrier cuts.

Our results suggest a number of possible avenues for future work. First, it would be desirable to obtain more data on non-tariff barriers and other impediments to trade. Second, the overall contribution of trade to wage inequality depends also on the sector bias of any induced effect of trade barriers on technical change. This may be worth examining.

Finally, our evidence that trade-barrier levels are highest in unskill-intensive sectors suggests there may be scope for future trade liberalizations to pressure U.S. unskilled wages. Figure 3 visualizes this: it plots the sector bias of hypothetical tariff cuts that in 1988, our last year of data, would have eliminated all U.S. tariffs. Free-trade tariff cuts would have been deeper in the unskill-intensive industries (the line of best fit for an employment-weighted regression of level changes on skill intensity is significantly positive at the $1 \%$ level). This evidence is only suggestive, but future research may want to explore this. 


\section{Data Appendix}

\section{Industry Tariffs}

These data come from Magee (1998). For each four-digit SIC industry in each year, Magee calculated the tariff rate as total duties collected as a share of the total customs value of imports. The original duties and imports data come from Feenstra (1996) according to the import-SIC industry classification and were concorded to the 1972 revision of the domestic SIC. All nominal values were converted to 1982 dollars using the economy-wide CPI for all consumers. These data start in 1974 because data on duties collected is not readily available for earlier years. Both the tariff data and full documentation for these data are available at the following web site: ftp://ftp.ssds.ucdavis.edu/pub/Econ/Feenstra/UStariff/.

\section{Transportation Costs}

These data come from data files in Feenstra (1996) which report for each four-digit SIC industry in each year imports (in millions of dollars) in terms of both c.i.f. (cost, insurance, and freight) values and customs value. For each observation we constructed transportation costs as (imports c.i.f. value imports customs value) as a share of the customs value of imports. By construction, these costs should be some value above zero. For the few observations reporting a c.i.f. valuation smaller than the customs valuation, we set transportation costs equal to zero.

\section{World Value Added}

These data come from United Nations (1996). For each industry-year in these data, we calculated the U.S. share of total world value added. These data were available only at the three-digit ISIC level; we mapped them into the four-digit 1972 SIC codes.

\section{Other Industry-Level Data}

All other industry-level data used in constructing factor-cost shares, price changes, etc., come from the Manufacturing Productivity Data Base of the NBER (1997). These data are available on line at http://www.nber.org. For a detailed description see Bartelsman and Gray (1997). 


\section{References}

Anderson, James E., and J. Peter Neary, "A New Approach to Evaluating Trade Policy," Review of Economic Studies, January 1996, 107-125.

Anderson, James E., and J. Peter Neary, "The Mercantilist Index of Trade Policy," NBER Working Paper \#6870, January 1999.

Bain, Joe S., Barriers To New Competition: Their Character and Consequences in Manufacturing Industries, 1948.

Baldwin, Robert E. and Glen G. Cain, "Shifts in U.S. Relative Wages: The Role of Trade, Technology, and Factor Endowments," NBER Working Paper \#5934, February 1997.

Bartelsman, Eric J. and Wayne Gray, "The NBER Manufacturing Productivity Database," NBER Technical Working Paper \#205, October 1996.

Berman, Eli, John Bound, and Stephen Machin. 1998. "Implications of Skill-Biased Technological Change: International Evidence." Quarterly Journal of Economics November, 1245-1280.

Berndt, Ernst R. and David O. Wood, "The Specification and Measurement of Technical Change in U.S. Manufacturing," in Advances in the Economics of Energy and Resources, Volume 4, JAI Press, 1982, pp. 199-221.

Crucini, Mario J., "Sources of Variation in Real Tariff Rates: The United States, 1900-1940," American Economic Review 84, June 1994, pp. 732-743.

Davis, Steven J., John C. Haltiwanger, and Scott Schuh, Job Creation and Destruction, 1998.

Deardorff, Alan and Dalia Hakura “Trade and Wages: What Are the Questions?", in Jagdish Bhagwati and Marvin Kosters (eds) Trade and Wages: Leveling Wages Down?, Washington, D.C.: American Enterprise Institute, 1994, pp. 36-75.

Feenstra, Robert C., "Symmetric Pass-Through of Tariffs and Exchange Rates Under Imperfect Competition: An Empirical Test," Journal of International Economics, 1989, 25-45.

Feenstra, Robert C., "U.S. Imports: Data and Concordances," NBER Working Paper \#5515 plus data CD-ROM (data also available on-line at http://www.nber.org), March 1996.

Feenstra, Robert C. and Gordon H. Hanson, "Productivity Measurement and the Impact of Trade and Technology on Wages: Estimates For the U.S., 1972-1990," NBER Working Paper \#6052, revised in Quarterly Journal of Economics, August 1999, pp. 907-940.

Findlay, Ronald and Harry Grubert, "Factor Intensities, Technological Progress, and the Terms of Trade," Oxford Economic Papers, 1959, Volume 11, pp. 111-121. 
Freeman, Richard B., "Are Your Wages Set in Beijing?" Journal of Economic Perspectives, Summer 1995, pp. 15-32.

Hanson, Gordon H., and Ann Harrison, "Trade Liberalization and Wage Inequali Industrial and Labor Relations Review 52, 1999, pp. 271-288.

Harrison, Ann, "Openness and Growth: A Time-Series, Cross-Country Analysis for Developing Countries," Journal of Development Economics, 1996, 419-447.

Haskel, Jonathan E., and Matthew J. Slaughter, "Trade, Technology, and U.K. Wage Inequality," NBER Working Paper \#6978, revised version December 1999.

Hummels, David, "Transportation Costs and International Integration in Recent History," mimeograph, February 1999.

Irwin, Douglas A., "Changes in U.S. Tariffs: The Role of Import Prices and Commercial Policies," American Economic Review, September 1998, pp. 1015-1026.

Keller, Wolfgang, "How Trade Patterns and Technology Flows Affect Productivity Growth," NBER Working Paper \#6990, March 1999.

Lawrence, Robert Z., and Matthew J. Slaughter, "International Trade and American Wages in the 1980s: Giant Sucking Sound or Small Hiccup?" in Martin Neil Baily and Clifford Winston (eds) Brookings Papers on Economic Activity: Microeconomics 2, 1993, pp. 161-211.

Leamer, Edward E., "In Search of Stolper-Samuelson Linkages Between International Trade and Lower Wages" in Susan M. Collins (ed), Imports, Exports, and the American Worker, Washington, D.C.: Brookings Institution Press, 1998, pp. 141-202.

Magee, Chris, "U.S. Tariffs at the SIC Level, 1974-1988," on-line data set downloadable from ftp://ftp.ssds.ucdavis.edu/pub/Econ/Feenstra/UStariff/, 1998.

National Bureau of Economic Research, Manufacturing Productivity Data Base, 1997.

Pritchett, Lant, "Measuring Outward Orientation: Can It Be Done?", Journal of Development Economics, May 1996.

Slaughter, Matthew J., "What Are the Results of Product-Price Studies and What Can We Learn From Their Differences?" in Robert C. Feenstra (ed), International Trade and Wages, National Bureau of Economic Research Conference Volume, forthcoming 1999.

United Nations, UNIDO Database, 1996. 
Figure 1a: U.S. Tariff Rates in 1974

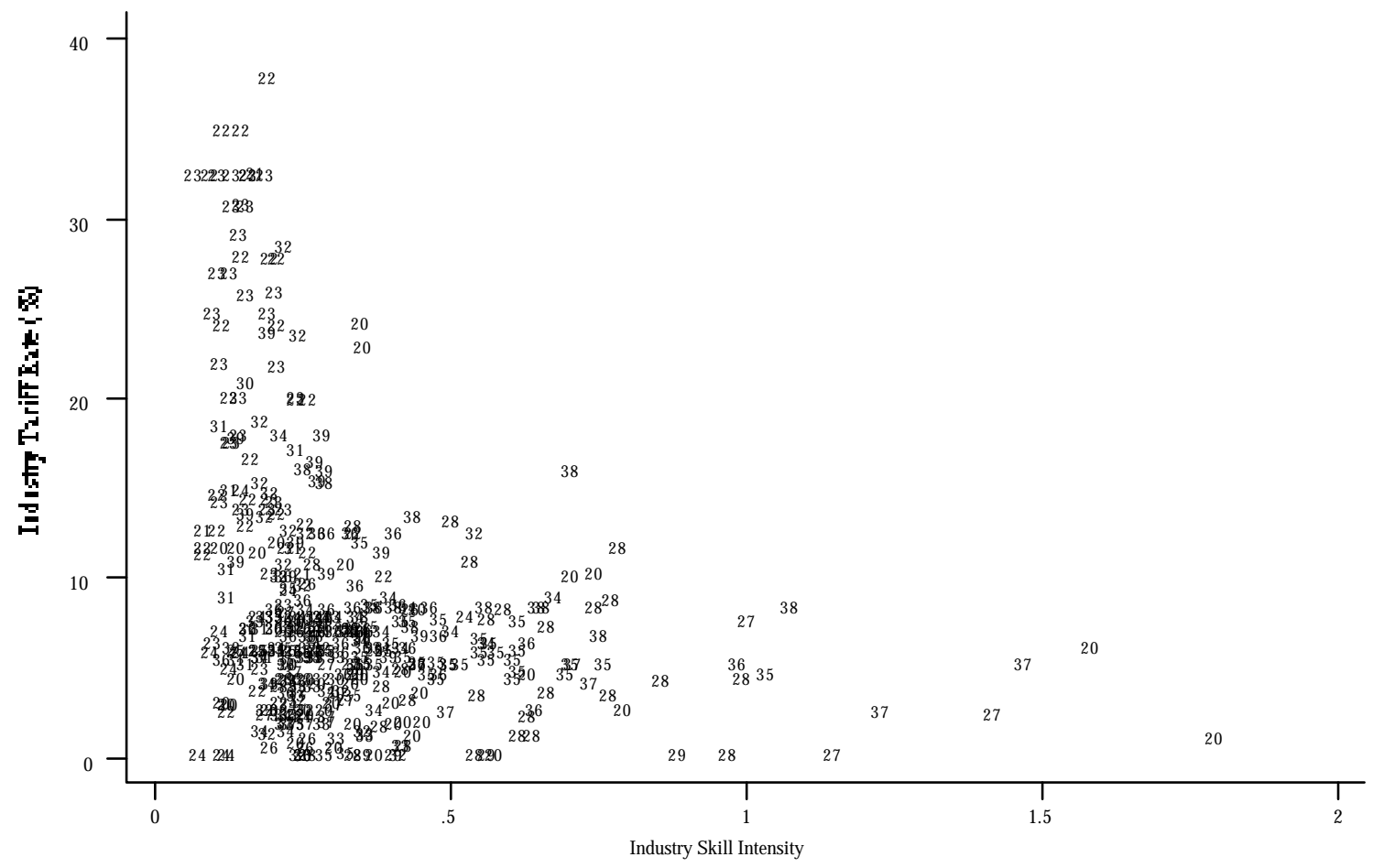

Figure 1b: U.S. Transportation-Cost Rates in 1974

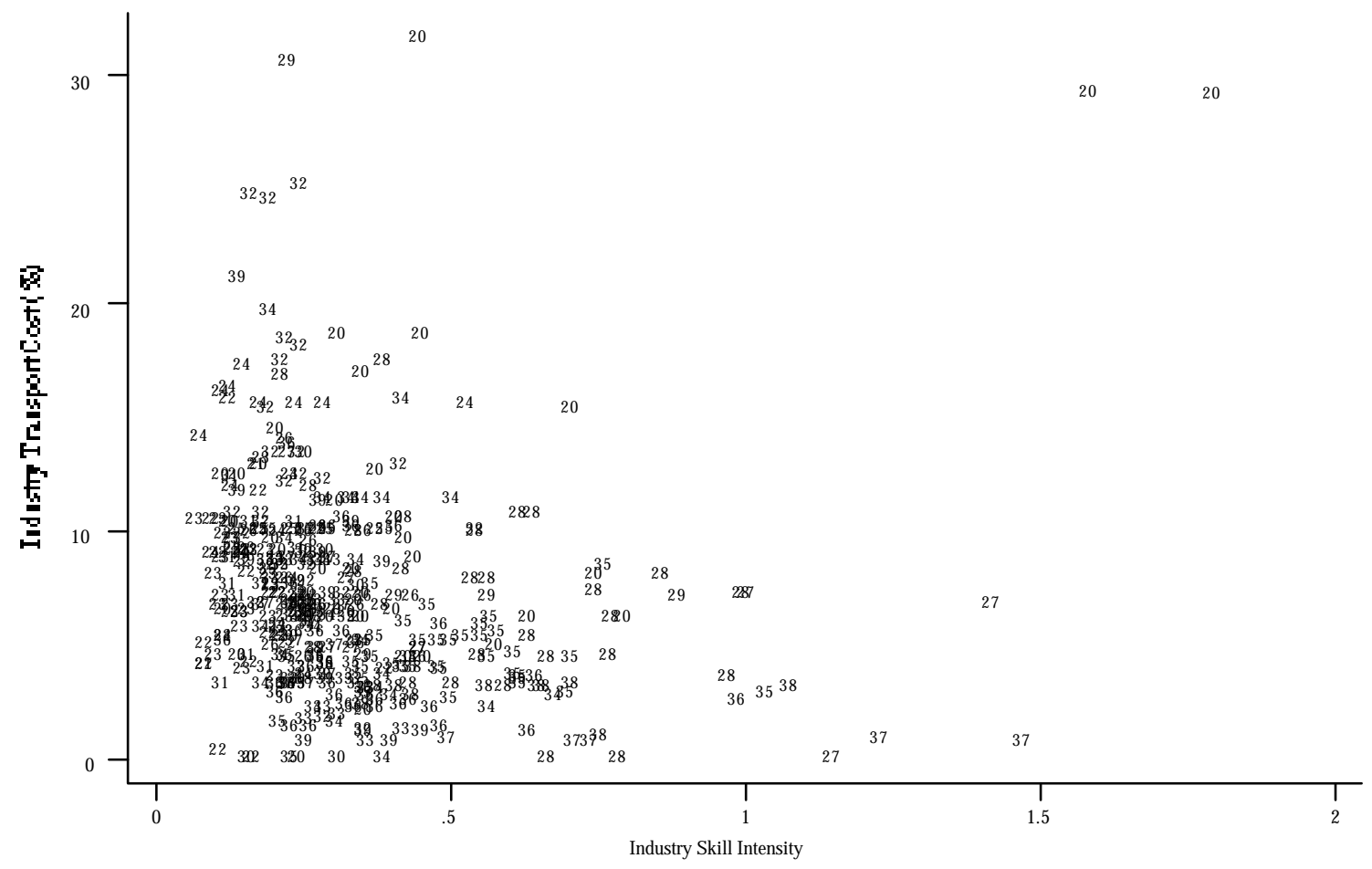

Notes: In each figure each observation is a four-digit SIC industry; for brevity, we report only the two-digit SIC code for each industry. Industry skill intensity is the relative employment of nonproduction to production workers. Tariff rates are duties collected as a share of the customs value of imports; transportation costs are (imports c.i.f. value - imports customs value) as a share of the customs value of imports. For readability we omitted two low-tariff skill-intensive industries: SIC 2721 (skill intensity of 4.52) and SIC 2731 (skill intensity of 2.86). Sources: Feenstra (1996), Magee (1998), and the NBER (1997). 

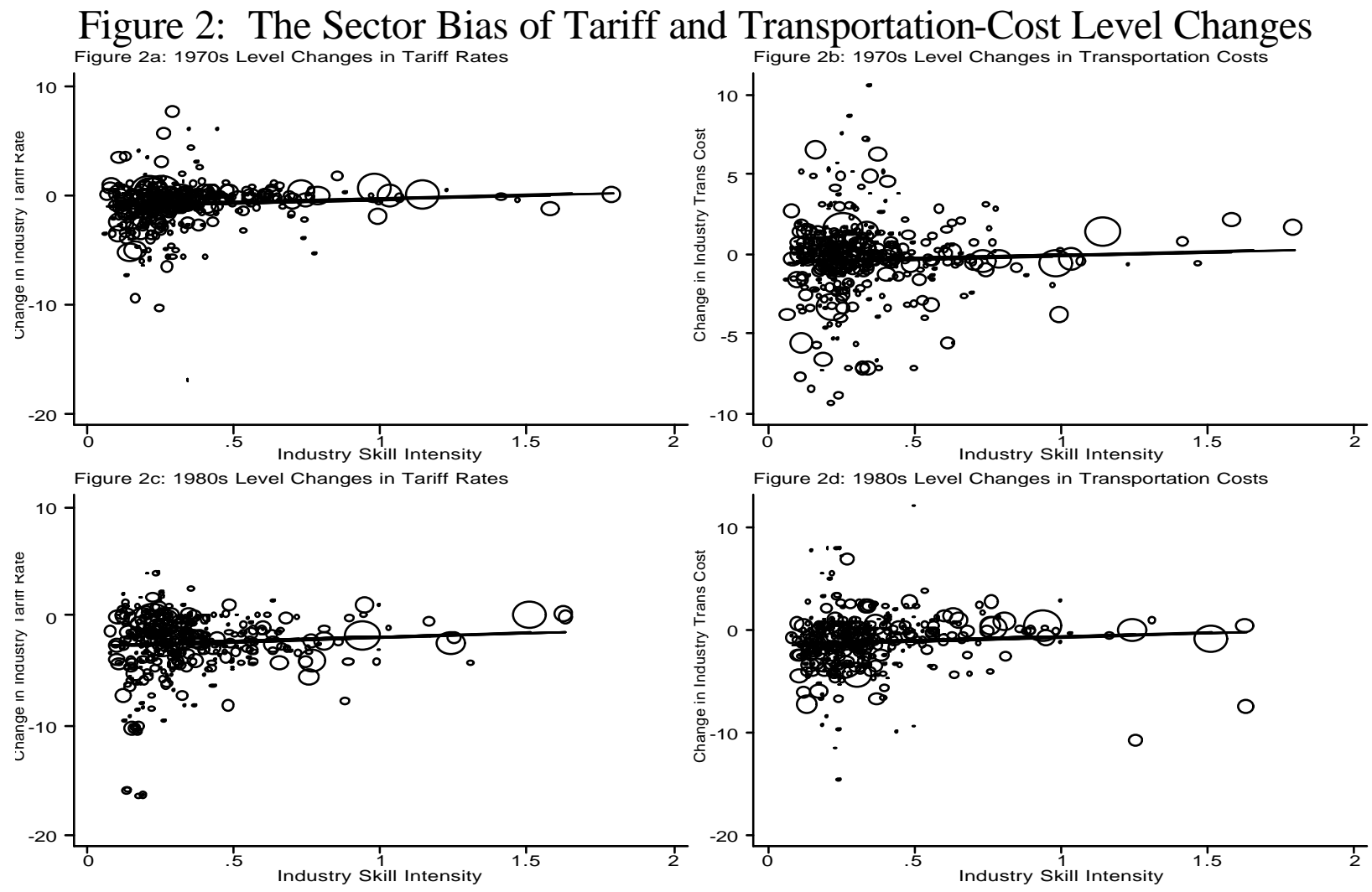

Figure 3: The Sector Bias of Free-Trade Tariff Cuts from 1988 Levels

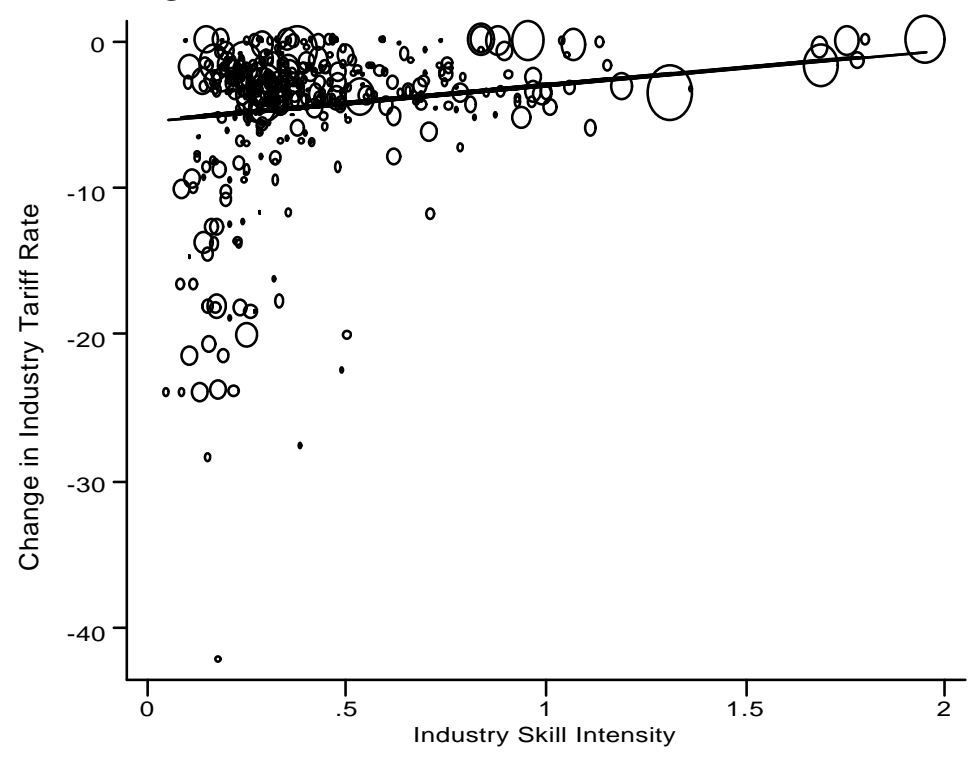

Notes: In each figure each observation is a four-digit SIC industry; circle sizes indicate industry average employment over the relevant decade. Each figure also contains the regression line of barrier changes on industry skill intensity, weighted by average employment, where industry skill intensity is the relative employment of nonproduction to production workers. In every panel the line is significantly positive at at least the $10 \%$ level (see text). Tariff rates are duties collected as a share of the customs value of imports; transportation costs are (imports c.i.f. value - imports customs value) as a share of the customs value of imports. For readability we omitted two skill-intensive industries: SIC 2721 (skill intensity of 4.52) and SIC 2731 (skill intensity of 2.86 ).

Sources: Feenstra (1996), Magee (1998), and the NBER (1997). 
Table 1: Summary Statistics, Levels of Tariffs and Transportation Costs

\begin{tabular}{ccccccc}
\hline \hline Variable & Observations & Mean & Median & Std. Dev. & Minimum & Maximum \\
\hline Tariff Rates, 1974 & 433 & 7.82 & 5.82 & 7.55 & 0.00 & 37.69 \\
Tariff Rates, 1979 & 435 & 6.80 & 5.24 & 6.69 & 0.00 & 34.64 \\
Tariff Rates, 1988 & 435 & 4.07 & 3.01 & 4.92 & 0.00 & 42.12 \\
Transport-Cost Rates, 1974 & 433 & 6.72 & 6.51 & 4.72 & 0.00 & 31.53 \\
Transport-Cost Rates, 1979 & 435 & 6.24 & 5.42 & 4.48 & 0.00 & 31.28 \\
Transport-Cost Rates, 1988 & 435 & 4.97 & 4.30 & 5.68 & 0.00 & 139.53 \\
\hline
\end{tabular}

Notes: These are employment-weighted summary statistics. Tariff rates are duties collected as a share of the customs value of imports; transportation costs are (imports c.i.f. value - imports customs value) as a share of the customs value of imports.

Sources: Feenstra (1996), Magee (1998), and the NBER (1997).

Table 2: Summary Statistics, Changes in Tariffs and Transportation Costs

\begin{tabular}{lcccccc}
\hline \multicolumn{1}{c}{ Variable } & Observations & Mean & Median & Std. Dev. & Minimum & Maximum \\
\hline Level Tariff Changes, 1970s & 433 & -0.77 & -0.37 & 1.72 & -17.02 & 7.47 \\
Level Tariff Changes, 1980s & 434 & -2.40 & -2.07 & 2.58 & -16.47 & 20.41 \\
Level T-C Changes, 1970s & 433 & -0.34 & -0.26 & 2.30 & -30.53 & 10.57 \\
Level T-C Changes, 1980s & 434 & -1.15 & -0.89 & 4.75 & -14.73 & 121.68 \\
& & & & & & $36,961.62$ \\
Percent Tariff Changes, 1970s & 433 & 262.01 & -7.12 & $3,094.47$ & -98.47 & $12,477.99$ \\
Percent Tariff Changes, 1980s & 434 & -10.51 & -36.62 & 461.62 & -100.00 & $3,265.88$ \\
Percent T-C Changes, 1970s & 433 & 65.99 & -3.19 & 464.56 & -100.00 & $40,483.53$ \\
Percent T-C Changes, 1980s & 434 & 433.93 & -18.10 & 3887.57 & -100.00 & 200.00 \\
Arc Tariff Changes, 1970s & 433 & -8.25 & -7.38 & 36.82 & -194.00 & 200.00 \\
Arc Tariff Changes, 1980s & 434 & -50.13 & -44.84 & 61.29 & -200.00 & 200.00 \\
Arc T-C Changes, 1970s & 433 & -5.81 & -3.23 & 57.56 & -200.00 & 200.00 \\
Arc T-C Changes, 1980s & 434 & -12.55 & -19.90 & 57.52 & -200.00 & 200 \\
\hline
\end{tabular}

Notes: These are employment-weighted summary statistics. Underlying all these changes, the tariff rates are duties collected as a share of the customs value of imports; transportation costs are (imports c.i.f. value - imports customs value) as a share of the customs value of imports. Level changes for each decade are constructed as the barrier's level at the end of the decade minus its level at the start of the decade. Percent changes for each decade are constructed as level changes divided by the initial-period level for that barrier. Arc changes for each decade are constructed as are arc-elasticities: these are level changes divided by the average level for that barrier over the decade. Sources: Feenstra (1996), Magee (1998), and the NBER (1997). 
Table 3

The Sector Bias of Tariff and Transportation-Cost Level Changes:

Estimates of (5) and (6)

(Dependent Variable: $\triangle T A R_{i t}$ and $\Delta T C_{i t}$ )

\begin{tabular}{|c|c|c|c|c|}
\hline & \multicolumn{3}{|c|}{ 1974-1979 } & \multirow{2}{*}{$\frac{1979-1988}{\Delta \text { Tran Costs }}$} \\
\hline & $\Delta$ Tariffs & $\Delta$ Tran Costs & $\Delta$ Tariffs & \\
\hline \multirow[t]{2}{*}{ Vs } & 5.305 & 8.662 & 0.439 & 6.113 \\
\hline & $(2.957)$ & $(3.201)$ & $(0.103)$ & (1.634) \\
\hline \multirow[t]{2}{*}{$\mathrm{Vu}$} & -6.622 & 0.087 & -11.963 & -5.284 \\
\hline & $(5.175)$ & $(0.065)$ & $(5.473)$ & $(2.085)$ \\
\hline \multirow[t]{2}{*}{$\mathrm{Vk}$} & -2.723 & -5.031 & -1.532 & 1.511 \\
\hline & (1.732) & (1.977) & $(0.856)$ & $(0.502)$ \\
\hline \multirow[t]{2}{*}{$(\mathrm{Vs}-\mathrm{Vu})$} & 28.21 & 8.07 & 5.12 & 4.98 \\
\hline & 0.00 & 0.00 & 0.02 & 0.03 \\
\hline R-Squared & 0.126 & 0.036 & 0.155 & 0.016 \\
\hline Observations & 433 & 433 & 435 & 435 \\
\hline
\end{tabular}

Notes: Cell entries are parameter estimates (and t-statistics for robust standard errors) for estimates of equations (5) and (6). The final row in each column reports the F-test for whether the coefficients are equal on the skilled and unskilled cost shares. For brevity the constant term is omitted. All regressions reported here are employment-weighted regressions; cost shares for each factor are constructed as that factor's share of industry shipments (using manufacturing-wide wages to construct these shares). Sources: Feenstra (1996), Magee (1998), and the NBER (1997). 
Table 4

Stage-One Price Regressions: Estimates of (3a) to (3e) (Dependent Variable: $\Delta \ln p_{i t}$ )

\begin{tabular}{|c|c|c|c|c|c|}
\hline & $(1)$ & (2) & (3) & (4) & (5) \\
\hline$\Delta T A R_{i t}$ & $\begin{array}{l}0.006 \\
(1.47)\end{array}$ & $\begin{array}{l}0.003 \\
(1.43)\end{array}$ & $\begin{array}{l}-0.003 \\
(0.27)\end{array}$ & $\begin{array}{l}-0.001 \\
(0.24)\end{array}$ & $\begin{array}{l}0.002 \\
(0.48)\end{array}$ \\
\hline$\Delta T C_{i t}$ & $\begin{array}{l}0.000 \\
(0.17)\end{array}$ & $\begin{array}{l}0.001 \\
(1.36)\end{array}$ & $\begin{array}{l}0.000 \\
(0.01)\end{array}$ & $\begin{array}{l}0.005 \\
(2.28)\end{array}$ & $\begin{array}{l}0.001 \\
(0.21)\end{array}$ \\
\hline$\Delta W O R L D V A_{g t}$ & & $\begin{array}{l}0.016 \\
(0.11)\end{array}$ & $\begin{array}{l}0.019 \\
(0.12)\end{array}$ & $\begin{array}{l}0.019 \\
(0.12)\end{array}$ & $\begin{array}{l}0.016 \\
(0.10)\end{array}$ \\
\hline$\Delta T F P_{i t}$ & & $\begin{array}{l}-0.708 \\
(12.49)\end{array}$ & $\begin{array}{l}-0.709 \\
(12.51)\end{array}$ & $\begin{array}{l}-0.711 \\
(12.64)\end{array}$ & $\begin{array}{l}-0.701 \\
(11.62)\end{array}$ \\
\hline$\triangle E X R A T E_{i t}$ & & $\begin{array}{l}-0.058 \\
(0.97)\end{array}$ & $\begin{array}{l}-0.059 \\
(0.99)\end{array}$ & $\begin{array}{l}-0.052 \\
(0.87)\end{array}$ & $\begin{array}{l}-0.059 \\
(0.97)\end{array}$ \\
\hline$\Delta T_{A R} R_{i t} \times U S O U T S H_{g t}$ & & & $\begin{array}{l}0.020 \\
(0.63)\end{array}$ & & \\
\hline$\Delta T C_{i t} \times U_{S O U T S H} H_{g t}$ & & & $\begin{array}{l}0.002 \\
(0.05)\end{array}$ & & \\
\hline$\Delta T A R_{i t} \times(K / L)_{i t}$ & & & & $\begin{array}{l}0.000 \\
(1.68)\end{array}$ & \\
\hline$\Delta T C_{i t} \times(K / L)_{i t}$ & & & & $\begin{array}{l}0.000 \\
(2.07)\end{array}$ & \\
\hline$\Delta T A R_{i t} \times C O N C_{i t}$ & & & & & $\begin{array}{l}0.000 \\
(0.14)\end{array}$ \\
\hline$\Delta T C_{i t} \times C O N C_{i t}$ & & & & & $\begin{array}{l}0.000 \\
(0.07)\end{array}$ \\
\hline R-squared & 0.757 & 0.915 & 0.915 & 0.917 & 0.918 \\
\hline $\begin{array}{l}\mathrm{P} \text { value for joint insignificance } \\
\text { of interacted variables }\end{array}$ & & & 0.82 & 0.10 & 0.98 \\
\hline Observations & 868 & 849 & 849 & 849 & 833 \\
\hline
\end{tabular}

Notes: Cell entries are parameter estimates (and absolute heteroskedastic-robust t-statistics) for estimates of equations (3a) through (3e). Specifications pool differences for 1974-79 and 1979-88 and include a time dummy and three digit fixed effects (not reported). Results are clustered around four-digit industries to account for common industries in the pooling. Estimation uses employment weights. The $\mathrm{P}$ value is for the joint insignificance of the interacted variables; a value over 0.05 suggests we can accept the null of joint insignificance with $95 \%$ confidence.

Sources: Feenstra (1996), Magee (1998), NBER (1997), UNIDO (1996) Census of Manufactures (various years), and Andrew Bernard. See text for details of variable construction. 


\section{Table 5 \\ Stage-Two Sector-Bias Regressions: Estimates of (4) for Tariffs (Dependent Variable: part of $\Delta \ln p_{i t}$ induced by $\Delta T A R_{i t}$ calculated from Table 4)}

\begin{tabular}{|c|c|c|c|c|c|}
\hline \multicolumn{6}{|c|}{ 1970s } \\
\hline & $(1)$ & (2) & (3) & (4) & $(5)$ \\
\hline \multirow[t]{2}{*}{ Vs } & 0.032 & 0.019 & 0.016 & 0.026 & 0.011 \\
\hline & $(1.00)$ & $(0.93)$ & $(0.64)$ & $(0.76)$ & $(0.36)$ \\
\hline \multirow[t]{2}{*}{$\mathrm{Vu}$} & -0.040 & -0.023 & -0.029 & 0.0001 & -0.016 \\
\hline & $(2.19)$ & $(2.10)$ & $(2.60)$ & $(0.01)$ & $(1.43)$ \\
\hline \multirow[t]{2}{*}{$\mathrm{Vk}$} & -0.016 & -0.009 & -0.011 & -0.019 & -0.005 \\
\hline & $(1.49)$ & $(1.40)$ & $(1.57)$ & $(1.30)$ & $(0.39)$ \\
\hline R-squared & 0.13 & 0.13 & 0.10 & 0.02 & 0.12 \\
\hline Observations & 424 & 424 & 424 & 424 & 424 \\
\hline Mandated rise in skill premium & $\begin{array}{l}7.2 \mathrm{pp} \\
(\mathrm{t}=1.45)\end{array}$ & $\begin{array}{l}4.2 \mathrm{pp} \\
(\mathrm{t}=1.35)\end{array}$ & $\begin{array}{l}4.7 \mathrm{pp} \\
(\mathrm{t}=1.27)\end{array}$ & $\begin{array}{l}2.6 \mathrm{pp} \\
(\mathrm{t}=0.65)\end{array}$ & $\begin{array}{l}2.7 \mathrm{pp} \\
(\mathrm{t}=0.74)\end{array}$ \\
\hline
\end{tabular}

1980s

\begin{tabular}{llllll}
\hline & $(1)$ & $(2)$ & $(3)$ & $(4)$ & $(5)$ \\
\hline $\mathrm{Vs}$ & 0.003 & 0.002 & -0.020 & 0.053 & 0.002 \\
& $(0.21)$ & $(0.24)$ & $(0.19)$ & $(1.18)$ & $(0.05)$ \\
$\mathrm{Vu}$ & -0.072 & -0.042 & -0.030 & 0.019 & -0.026 \\
$\mathrm{Vk}$ & $(1.51)$ & $(1.47)$ & $(0.51)$ & $(0.53)$ & $(0.99)$ \\
& -0.009 & -0.005 & -0.014 & -0.029 & -0.006 \\
& $(1.19)$ & $(1.03)$ & $(2.27)$ & $(0.97)$ & $(0.27)$ \\
R-squared & & & & & \\
Observations & 0.02 & 0.15 & 0.09 & 0.07 & 0.12 \\
Mandated rise in skill premium & 425 & 425 & 425 & 425 & 425 \\
& $7.5 \mathrm{pp}$ & $4.4 \mathrm{pp}$ & $1.0 \mathrm{pp}$ & $3.4 \mathrm{pp}$ & $4.6 \mathrm{pp}$ \\
& $(\mathrm{t}=2.00)$ & $(\mathrm{t}=1.88)$ & $(\mathrm{t}=0.06)$ & $(\mathrm{t}=1.01)$ & $(\mathrm{t}=0.61)$ \\
\hline
\end{tabular}

Notes: Cell entries are parameter estimates (and absolute t-statistics) for estimates of equation (4). Each column here corresponds to the similarly-numbered column for one of the first-stage regressions from Table 4. In each column the last row reports the mandated rise in the skill premium, calculated as the coefficient on $V s$ minus the coefficient on $V u$ ("pp" stands for percentage points). The t-statistic is for the test of whether this mandated rise in inequality is significantly different from zero. " $\mathrm{n} / \mathrm{a}$ " denotes we are unable to calculate the particular standard error by our process correcting for the generated regressand, see footnote 12. All results are for employment-weighted regressions.

Sources: Feenstra (1996), Magee (1998), NBER (1997). See text for details of variable construction. 


\section{Table 6}

\section{Stage-Two Sector-Bias Regressions: Estimates of (4) for Transportation Costs (Dependent Variable: part of $\Delta \ln p_{i t}$ induced by $\Delta T C_{i t}$ calculated from Table 4)}

1970s

\begin{tabular}{llllll}
\hline & $(1)$ & $(2)$ & $(3)$ & $(4)$ & $(5)$ \\
\hline $\mathrm{Vs}$ & 0.001 & 0.006 & 0.007 & -0.008 & 0.007 \\
& $(0.21)$ & $(1.19)$ & $(\mathrm{n} / \mathrm{a})$ & $(0.48)$ & $(0.24)$ \\
$\mathrm{Vu}$ & 0.0001 & 0.0002 & 0.0004 & -0.009 & 0.001 \\
& $(\mathrm{n} / \mathrm{a})$ & $(0.31)$ & $(0.10)$ & $(1.60)$ & $(\mathrm{n} / \mathrm{a})$ \\
$\mathrm{Vk}$ & -0.001 & -0.004 & -0.003 & 0.008 & -0.003 \\
& $(0.24)$ & $(1.66)$ & $(1.21)$ & $(1.08)$ & $(0.25)$ \\
& & & & & \\
Observations & 433 & 433 & 433 & 433 & 433 \\
R-squared & 0.04 & 0.04 & 0.03 & 0.02 & 0.03 \\
Mandated rise in skill premium & $0.1 \mathrm{pp}$ & $0.6 \mathrm{pp}$ & $0.7 \mathrm{pp}$ & $0.1 \mathrm{pp}$ & $0.6 \mathrm{pp}$ \\
& $(\mathrm{n} / \mathrm{a})$ & $(\mathrm{t}=1.08)$ & $(\mathrm{n} / \mathrm{a})$ & $(\mathrm{t}=0.08)$ & $(\mathrm{n} / \mathrm{a})$ \\
\hline
\end{tabular}

1980s

\begin{tabular}{llllll}
\hline & $(1)$ & $(2)$ & $(3)$ & $(4)$ & $(5)$ \\
\hline $\mathrm{Vs}$ & 0.001 & 0.004 & 0.003 & 0.005 & 0.005 \\
& $(0.22)$ & $(0.61)$ & $(0.26)$ & $(0.18)$ & $(0.12)$ \\
$\mathrm{Vu}$ & -0.001 & -0.004 & -0.003 & -0.021 & -0.003 \\
& $(0.14)$ & $(1.04)$ & $(0.49)$ & $(1.72)$ & $(1.54)$ \\
$\mathrm{Vk}$ & 0.0002 & 0.001 & 0.002 & 0.012 & 0.001 \\
& $(0.39)$ & $(0.69)$ & $(1.73)$ & $(1.40)$ & $(0.09)$ \\
& & & & & \\
Observations & 435 & 435 & 435 & 435 & 435 \\
R-squared & 0.02 & 0.02 & 0.02 & 0.05 & 0.02 \\
Mandated rise in skill premium & $0.2 \mathrm{pp}$ & $0.8 \mathrm{pp}$ & $0.1 \mathrm{pp}$ & $2.6 \mathrm{pp}$ & $0.8 \mathrm{pp}$ \\
& $(\mathrm{t}=0.16)$ & $(\mathrm{t}=0.77)$ & $(\mathrm{t}=0.33)$ & $(\mathrm{t}=1.26)$ & $(\mathrm{t}=0.19)$ \\
\hline
\end{tabular}

Notes: Cell entries are parameter estimates (and absolute t-statistics) for estimates of equation (4). Each column here corresponds to the similarly-numbered column for one of the first-stage regressions from Table 4. In each column the last row reports the mandated rise in the skill premium, calculated as the coefficient on $V s$ minus the coefficient on $V u$ ("pp" stands for percentage points). The t-statistic is for the test of whether this mandated rise in inequality is significantly different from zero. " $\mathrm{n} / \mathrm{a}$ " denotes we are unable to calculate the particular standard error by our process correcting for the generated regressand, see footnote 12. All results are for employment-weighted regressions.

Sources: Feenstra (1996), Magee (1998), UNIDO (1996). See text for details of variable construction. 